Article

\title{
Shifting Coalitions within the Youth Climate Movement in the US
}

\author{
Dana R. Fisher ${ }^{1, *}$ and Sohana Nasrin ${ }^{2}$ \\ ${ }^{1}$ Department of Sociology, University of Maryland, College Park, MD 20742, USA; E-Mail: drfisher@umd.edu \\ 2 Philip Merrill College of Journalism, University of Maryland, College Park, MD 20742, USA; \\ E-Mail: sohana@terpmail.umd.edu \\ * Corresponding author
}

Submitted: 30 October 2020 | Accepted: 22 December 2020 | Published: 28 April 2021

\begin{abstract}
How has the youth climate movement in the US grown since the Climate Strikes began and in what ways did it change as it grew? This article takes advantage of a unique dataset that includes surveys from activists who organized the nationally coordinated climate strikes in the US that began with Fridays for Future in spring 2019. Building on the research on alliance building and strategic coalitions, this article analyzes how the patterns of participation changed over the period of the study. We employ social network analysis to map the affiliation networks among the organizers of these events to assess the coalitions of groups involved and the shifting organizational landscape. Our analysis does not provide evidence that groups spanned the boundaries across movements, nor does it show that identity played a role in coalition building in this movement. Instead, by mapping out the coalition of organizations within this movement and how connections among them change over time, we see clear evidence that this youth-led movement was reoriented by adult-led organizations. Our article concludes by considering how these findings suggest the future trajectory of the youth climate movement and its role in a 'new climate politics' in America.
\end{abstract}

\section{Keywords}

activism; climate change; climate movement; climate strike; coalitions; social network analysis

\section{Issue}

This article is part of the issue "Is There a New Climate Politics? Emergency, Engagement and Justice" edited by Anna R. Davies (Trinity College Dublin, Ireland), Stephan Hügel (Trinity College Dublin, Ireland) and Vanesa Castán Broto (University of Sheffield, UK).

(C) 2021 by the authors; licensee Cogitatio (Lisbon, Portugal). This article is licensed under a Creative Commons Attribution 4.0 International License (CC BY).

\section{Introduction}

On 20 August 2018, Greta Thunberg participated in the first climate strike ever. Inspired by the national school walkout against gun violence in the US that was organized after the Parkland School Shooting in Florida, the 15 year-old decided to spend her Fridays sitting with a hand written sign in front of the Swedish parliament. Since that Friday in August, Fridays for Future-the name of the group coordinating this tactic of skipping school on Fridays to protest inaction on climate change-has spread across the seas and around the world. In March 2019, the first 'global' climate strike took place, turning out more than one million people around the world
(Carrington, 2019). Six months later in September 2019, young people and adults responded to a call by Thunberg and other young activists to participate in climate strikes as part of the Global Week for Future surrounding the UN Climate Action Summit (Thunberg, 2019), and the number of participants globally jumped to an estimated 7,6 million people (350.org Team, 2019).

In the US, the youth climate movement has also grown. As school strikes have become more common, the initial vanguard of young Americans who were inspired by Thunberg along with their personal experiences with climate change were joined by activists who originally cut their teeth in the anti-Trump Resistance (Fisher, 2019c; for a broader discussion of the Resistance, 
see Fisher, 2019a). At the same time, groups that were founded specifically to organize young people around the issue of climate change joined in coalition with more established climate groups, as well as less climatefocused organizations to mobilize participants to join the growing movement. Although participation in these climate strikes and the broader youth climate movement expanded over the past two years, there is limited research on the movement to date (cf. de Moor, De Vydt, Uba, \& Wahlström, 2020; Evensen, 2019; Fisher, 2019b; Fisher \& Nasrin, 2020; Martiskainen et al., 2020).

This article provides empirical evidence regarding how the youth climate movement has grown in the US since the globally coordinated Climate Strikes began in spring 2019. We analyze a unique dataset that includes surveys from 522 activists who helped to organize the nationally coordinated climate strikes in the US that began with Fridays for Future in 2019. Specifically, this article builds on the research on coalition building in social movements to analyze how the patterns of collaboration changed over the period of the study, in terms of the organizational networks of the coordinators of these climate strikes. We employ social network analysis to map out the affiliation networks among the individuals involved as a means of assessing the shifting organizational landscape. By analyzing what are the dominant organizational nodes in the movement and how they are connected, our findings show how the coalition changed over time.

This article is separated into three sections. First, we present a brief review of the literature, paying particular attention to the ways that the extant research has understood the role of organizational coalitions in social movements. Second, we provide details of the data we collected and the methods used to analyze organizational coalitions within the youth climate movement. Third, we present the results of our analysis and discuss the implications of our findings on a growing movement that has been forced to change due to a global pandemic.

\section{Alliance Building and Strategic Coalitions}

In recent years, scholars of social movements have paid substantial attention to the role that alliance building and strategic coalitions play in growing and maintaining movements of all sorts (Barkan, 1979; Fantasia \& Stepan-Norris, 2007; Fantasia \& Voss, 2004; Ferree \& Hess, 2016; Grimm, 2019; Levi \& Murphy, 2006; McAdam, 1982, 1983, 1983; Meyer \& Corrigall-Brown, 2005; Polletta, 2002; Shaffer, 2000; Staggenborg, 1991; Thomas \& Trevino, 1993; Van Dyke \& McCammon, 2010; Wang, Piazza, \& Soule, 2018). Research has looked at coalitions of organizations that work within a single social movement (see e.g., Heaney \& Rojas, 2008; Morris, 1993), as well as coalitions across movements that span boundaries (Wang et al., 2018; see also Beamish \& Luebbers, 2009; Meyer \& Whittier, 1994; Van Dyke, 2003). In her study of movement activity among college students, Van Dyke compares coalitions, finding that "local threats inspire within-movement coalition events, while larger threats that affect multiple constituencies or broadly defined identities inspire cross-movement coalition formation" (Van Dyke, 2003, p. 226).

Some of this research specifically looks at how coalitions and strategic alliances are associated with successful movement outcomes (Gamson, 1990; Grimm, 2019; Levi \& Murphy, 2006; Morris, 1993; Steedly \& Foley, 1979; Van Dyke, 2003). In her well-known study of the pro-choice movement, Staggenborg (1991) discusses how organizational coalitions help groups compensate for their lack of resources and organizational insufficiencies to generate grassroots supports (see also Borland, 2008; Wang et al., 2018). Similarly, when Beamish and Luebbers (2009) look at the coalition among environmental justice, peace, and anti-weapons proliferation groups, they find that successful coalitions involve ongoing social interactions that help to reduce the potential for intergroup conflicts. When conflicts and differences in perspective are not addressed, they can "erode membership, break down collective incentives and commitments, and thus undermine social movement efficacy" (Beamish \& Luebbers, 2009, p. 647; see also Barkan, 1979; Bliuc, Betts, Vergani, Iqbal, \& Dunn, 2019; Cárdenas \& de la Sablonnière, 2020; Freeman, 1972; Gamson, 1990; Lichterman, 1996; Staggenborg, 1991).

To date, there have been a handful of studies that examine how intersectionality contributes to social movements (Heaney \& Rojas, 2015; see also Milkman, 2017; Swank \& Fahs, 2013; Terriquez, 2015). Scholars have used intersectionality as a theory, an analytical framework (Cho, Crenshaw, \& McCall, 2013; Choo \& Ferree, 2010; Crenshaw, 1991), as well as a method (Hancock, 2007) to examine how intersections of race, class, gender, sexual orientation, legal status, and other categories of identity are linked to structures of inequality and produce different life experiences and forms of oppression or privilege (for a general discussion of intersectionality, see Cho et al., 2013; Choo \& Ferree, 2010; Collins, 2002; Crenshaw, 1991; Valentine, 2007). The definition of intersectionality and its applications have evolved over time. Intersectionality was originally developed by legal scholar Kimberlé Crenshaw (1991) to explain how African American women faced challenges when pursuing claims of employment discrimination. Although it originated in discussions of women of color, contemporary research on intersectionality aims to explain the experiences and complexities of both marginalized and privileged groups in society (Carbado, 2013; Cho et al., 2013; Shows \& Gerstel, 2009; Wingfield, 2009). Some scholars have suggested that these intersections divide people into silos characterized by distinct and competing interests that prevent the kind of coalition building that is necessary for strong social movement organizing. For example, intersectionality has been criticized as producing 'identity politics' that focuses on narrow group interests at the expense of broader political claims (Brown, 1995; Ehrenreich, 2002). 
At the same time, a limited number of studies of collective action have specifically explored how intersectional interests can be used to build coalitions within and across social movements, thereby increasing the number and diversity of activists (Adam, 2017; Carastathis, 2013; Fisher, Dow, \& Ray, 2017; Fisher, Jasny, \& Dow, 2018; Goss \& Heaney, 2010; Roberts \& Jesudason, 2013; Wadsworth, 2011). In her influential work, Kimberlé Crenshaw (1991) suggests that intersectionality-which highlights the intersections of race, gender, social class, and other social qualities - can promote coalitions instead of divisions (see also Hancock, 2007). Identity-based groups are recognized as spaces of similarity, seclusion, and safety (Reagon, 1983). Building directly off of the work of Crenshaw (1991), Carastathis (2013, p. 941) makes a case for thinking about identity groups as coalitions that facilitates "effective political coalitions that cross existing identity categories." In other words, not only can coalitions be formed by spanning movement boundaries (see especially Wang et al., 2018), but they can combine efforts of people with different identities in a common struggle. Within this research, some studies have specifically explored intersectional mobilization processes and how shared grievances play a role (see Terriquez, 2015).

In their study of the overlapping motivations of protest participants, Fisher et al. (2017) provide evidence for these claims by looking at how intersectionality mobilized activists to join the first Women's March in 2017. The authors conclude that:

Individuals were more likely to be motivated by issues connected to the social identities that were most salient for them: Black participants mobilized for Racial Justice, Hispanic participants mobilized for Immigration, and women mobilized for Reproductive Rights. Our analysis supports previous studies that find that individuals concerned with a range of social issues can establish and build coalitions informed by intersectional motivations. (Fisher et al., 2017, p. 5; see also Fisher et al., 2018)

\subsection{Using Network Analysis to Study Coalitions}

Much of the research studying coalitions within social movements focuses specifically on the role of social ties and social networks to facilitate connections among individuals and organizations (Gould, 1991; Heaney \& Rojas, 2008; Kim \& Bearman, 1997; Klandermans \& Oegema, 1987; Marwell, Oliver, \& Prahl, 1988; Mische \& Pattison, 2000; Park, 2008; Rosenthal, Fingrutd, Ethier, Karant, \& McDonald, 1985). Numerous studies have concluded that individuals' ties to organizations play an important role in mobilizing activists (Passy, 2003; Saunders, Grasso, Olcese, Rainsford, \& Rootes, 2012; for an overview, see Diani \& McAdam, 2003). Moreover, social networks analysis has been employed to study how movements are expanded and connected to other groups. Studying the Italian environmental movement, for example, Diani shows how networks in social movements are largely formed based on members' socialization experience, issues priorities, and organizational differences (Diani, 1995). In their edited volume, Diani and McAdam (2003) discuss how networks facilitate inter-organizational alliances that can strengthen social movements. In other cases, research has employed social network analysis to analyze when coalitions fall apart (see particularly Heaney \& Rojas, 2008).

In his piece in The Blackwell Companion to Social Movements, Diani outlines the ways that analysis of individual activists and their organizational affiliations can explore "how activists connect groups" to understand "the web of multiple ties that ultimately make up a social movement" (Diani, 2007, pp. 348, 339; see also Diani, 2010; Diani, Lindsay, \& Purdue, 2010; Heaney \& Rojas, 2008; Rosenthal et al., 1985). Consistent with this work that employs social network analysis, our article builds on the research on coalitions among social movement organizations to assess how the affiliation networks of the organizers in the Youth Climate Movement in the US changed during the period of our study. Though our analysis, we are able to assess the degree to which organizational coalitions in this movement cross movements, issues, and identities over time.

\section{Data and Methods}

This article integrates data collected through three waves of online surveys of the hosts of the events coordinated by the youth climate movement from 2019-2020. 'Hosts' are the term used by the movement to describe the locallevel of organizers for climate strikes; they were responsible for coordinating local mobilization and logistics. Data were collected from these hosts who worked on the internationally coordinated climate strikes in the US in spring 2019, the Global Climate Strike in September 2019, and for Earth Day Live in April 2020. In total, the dataset includes surveys from 522 activists who helped to organize the nationally coordinated climate strikes in the US that began with Fridays for Future. In the sections that follow, we describe each wave of data collection.

\subsection{Data Collection from the US Hosts of Fridays for Future in Spring 2019}

To begin this project, data were collected from the US-based hosts who coordinated the 2019 spring climate strikes in March and May. Contact information for organizers of the strikes was collected from the group that coordinated the events: Fridays for Future. The official website of Fridays for Future includes information for any organizer who is willing to share their information by date and location of event. An individual link to an internet-based survey was shared with everyone who signed up with Fridays for Future to organize a US-based strike. The survey yielded a $21 \%$ response rate. To make sure that all youth climate activists who had 
been involved in organizing climate strikes in the US were included in the sample, an anonymous link was also shared via groups working specifically to engage young people in the US around the issue of climate change. In total, 220 people completed the survey.

\subsection{Data Collection from the US Hosts from the Global Climate Strike}

Following the success of the spring 2019 climate strikes, Greta Thunberg and other young activists called for adults to join young people in the streets for climate strikes that were coordinated as part of the 'Global Week for Future' surrounding the UN Climate Action Summit in September 2019 (Thunberg, 2019). The strikes turned out estimated 7,6 million people globally and over 500,000 people in the US (350.org Team, 2019). Working with one of the coordinating organizations for the September strikes in the US-Future Coalition, which coordinated the StrikeWithUs website-we conducted an online survey of all of the hosts of the 633 events being coordinated around the US as part of the Global Climate Strike on 20 September 2019. An initial email and two reminders that included an anonymous link to our survey were sent out by the organization to their list of climate strike hosts before the event. The email requested that they participate in our study. In total, 131 hosts completed the survey, representing a $21 \%$ response rate.

\subsection{Data Collection from the US Hosts of Earth Day Live}

In early 2020, organizers were planning for even larger strikes and demonstrations and were working to coordinate a huge event to coincide with the 50th anniversary of Earth Day in April. However, with the global spread of Covid-19 and the enforcement of social distancing, climate activists called off their in-person protests and worked to move their activism online (Thunberg, 2020). In the US, the organizational coalition that was working to plan a three-day climate strike in April transitioned their efforts to coordinate a three-day digital event called 'Earth Day Live,' which was scheduled to take place from 22-24 April 2020 by the US Climate Strike Coalition of youth-led organizations. As part of the event, organizers encouraged activists to participate in numerous activities including virtual protests, tweet storms, hashtag activism that targeted specific corporations, and posting selfies with signs. It is worth noting that this event was independent of the commemoration of the anniversary of Earth Day, which was also called 'Earth Day Live' and was coordinated by the adult-led group: Earth Day Network.

Like data collection for the Global Climate Strike in September 2019, data for this wave of the study were collected through one of the leaders of the organizational coalition for the event: Future Coalition. The organization shared an anonymous link to the survey via an email and two follow-up reminders with their list of all of the local hosts of the Earth Day Live mobilization in the US. The link was shared with the 1,269 people who had signed up to host any of the events that they had coordinated over the year. This list included 442 individuals who signed up specifically to serve as a host for the Earth Day Live event. In total, 171 hosts completed the survey (representing a response rate of $14 \%$ of the total list of organizers and $39 \%$ of the people specifically signed up for this event in April 2020). Table 1 presents an overview of the data included in this article.

\section{Findings}

We begin by presenting an overview of the data collected from these three waves of youth climate activism in the US. Next, we discuss our analytic technique for analyzing the affiliation networks of the organizers of this movement. Finally, we present the results of our network analysis that shows how the organizational coalitions changed over the period of our study.

\subsection{Overview of the Dataset}

Consistent with other studies of activism during this period of heightened contention in the US (see e.g., Fisher, 2019a; Fisher et al., 2019), organizers during all three waves of the movement-in spring 2019, fall 2019, and spring 2020-were predominantly female $(66 \%, 68 \%$, and $65 \%$ respectively), majority White $(67 \%$, $77 \%$, and $72 \%$ respectively), and came from highly educated families. During all three waves, the majority of participants reported coming from households with parents/guardians who had completed an undergraduate degree or higher. In other words, there is consistency in

Table 1. Overview of data collected.

\begin{tabular}{lccc}
\hline & $\begin{array}{c}\text { Spring Climate Strike } \\
\text { Organizers }\end{array}$ & $\begin{array}{c}\text { Global Climate Strike } \\
\text { Organizers }\end{array}$ & $\begin{array}{c}\text { Earth Day Live } \\
\text { Organizers }\end{array}$ \\
\hline Date of event(s) & 15 March and 24 May 2019 & 20 September 2019 & $22-24$ April 2020 \\
Number of Events & 163 & 633 & 442 \\
Number of Respondents & 220 (35 from Fridays for Future) & 131 & 171 \\
Response Rate & $21 \% *$ & $21 \%$ & $39 \%$ \\
\hline
\end{tabular}

Note $={ }^{*}$ Percentage based on the number of respondents who had organized with Fridays for Future. 
the identities of the participants at each strike. Although it is possible that these findings are due, in part, to response biases in the methodology, these patterns regarding the gender, race, and educational attainment of our dataset are consistent with previous research on the demographics of the environmental and climate movements in the US (Giugni \& Grasso, 2015; see also Fisher et al., 2019).

As expected, organizers in this movement were young. However, the median age of the hosts went up substantially over the period of our study: Hosts of the spring 2019 strikes reported a median age of only 18 years-old, those organizing in fall 2019 reported a median age of 25, and the organizers for Earth Day Live in April 2020 had a median age of 32 .

\subsection{Organizational Affiliations of Hosts}

As previously noted, our analysis focuses on the affiliations of the hosts in this movement and employs social network analysis to map out how the organizational coalition changes over time (Diani, 2007; Heaney \& Rojas, 2008; Rosenthal et al., 1985; see also Mische \& Pattison, 2000). Data are based on respondents' responses to the question: "Are you a member of any organization or group that is involved in the global climate strike or youth climate movement?" If respondents said yes to this question, they were asked to write in the names of up to three groups. The overall number of groups named by each individual organizer goes down during this time period: In summer 2019, respondents mentioned being affiliated with an average of 2.9 groups per respondent; in fall 2019, respondents answered 1.8 groups per person; and in spring 2020, respondents mentioned 1.7 groups per respondent.

\subsubsection{Most Common Organizations in Each Wave}

Next, we look at what organizations were mentioned the most in each wave of data collection to understand the overall organizational ecosystem of the youth climate movement. Table 2 presents the counts of the top organizations mentioned in each wave of data collection along with the percentage each group received. We list all organizations that received five or more mentions during at least one wave of the study.

Although Sunrise was consistently the most mentioned organization during each wave of the study, the other most mentioned organizations changed over time. During the first wave of the study in summer 2019, the top three groups were Sunrise, US Youth Climate Strike, and Fridays for Future-all of which are youth-led organizations. In fall 2019, organizers named Sunrise, 350 and US Youth Climate Strike as the most common groups. It is worth noting that 350 is an environmental organization that was founded in 2008 by "a group of university friends in the US along with author Bill McKibben...to build a global climate movement" (350.org Team, 2021). Even though it was founded by young people in 2008, it has grown to be a professionalized environmental group that is adult-led. In spring 2020, Sunrise continued to be the most mentioned group with almost a quarter of all respondents (23\%) reporting being affiliated with it. The other most mentioned organizations were both adult-led environmental groups: 350 and the Sierra Club. Even though more general organizations were in the network, based on these findings, there is no evidence of groups that span boundaries playing a substantial role in this coalition (Wang et al., 2018; see also Beamish \& Luebbers, 2009).

\subsection{Analyzing Organizational Affiliation Networks}

Building directly off Diani's work (2007), the next step in our analysis is mapping out the affiliation networks of the organizers of the climate strikes to understand the co-occurrence of membership in groups. Comparing these affiliation networks over time, we are able to see more clearly how the coalition changed during the period of study. Before presenting the affiliation networks of these climate activists over time, we discuss our analytic technique.

Table 2. Counts of top organizations and frequency by sample (all groups with 5 or more mentions).

\begin{tabular}{|c|c|c|c|}
\hline Organization & $\begin{array}{c}\text { Spring Climate Strike } \\
\text { Organizers } \\
(\mathrm{N}=220)\end{array}$ & $\begin{array}{c}\text { Global Climate Strike } \\
\text { Organizers } \\
(\mathrm{N}=131)\end{array}$ & $\begin{array}{c}\text { Earth Day Live } \\
\text { Organizers } \\
(\mathrm{N}=171)\end{array}$ \\
\hline Sunrise & $27(12 \%)$ & $23(18 \%)$ & $39(23 \%)$ \\
\hline US Youth Climate Strike & $21(10 \%)$ & $12(9 \%)$ & $10(6 \%)$ \\
\hline Fridays For Future & $19(9 \%)$ & $2(2 \%)$ & $3(2 \%)$ \\
\hline Extinction Rebellion & $13(6 \%)$ & $4(3 \%)$ & $8(5 \%)$ \\
\hline Schools for Climate Action & $9(4 \%)$ & 0 & $1(1 \%)$ \\
\hline This is Zero Hour & $7(3 \%)$ & $1(1 \%)$ & $6(4 \%)$ \\
\hline 350 & $5(2 \%)$ & $16(12 \%)$ & $32(19 \%)$ \\
\hline Sierra club & $3(1 \%)$ & $5(4 \%)$ & $14(8 \%)$ \\
\hline
\end{tabular}




\subsubsection{Network Analysis Technique}

We visualized the organizational coalitions as an actororganization affiliation network by creating a bipartite graph for each climate strike separately. In these networks, hosts (who are respondents in the survey) are represented by grey diamonds and organizations with which they are affiliated are represented by green circles. The groups that are youth-led are depicted as a light green circles and those groups that are adult-led are depicted as a dark green circles. The ties between a host and an organization are represented as a line. Node size of the organizations corresponds to the degree centrality of the group. By mapping out co-occurrence of organizational affiliation, these visualizations provide more evidence about the coalition in terms of who is playing a central role and how organizations are related to one another in terms of sharing members, as well as how they change over time.

Affiliation networks for each wave of the study are presented in the next section. Consistent with Table 2, only groups that were mentioned by at least five respondents during at least one wave of the survey are included in the analysis. Groups that received zero mentions during a particular wave are absent from that specific network diagram.

\subsubsection{Spring 2019 Climate Strike Affiliation Network}

The affiliation network of organizers from the spring 2019 climate strikes are presented in Figure 1. The diagram shows clear evidence that the coalition is being steered by youth-led groups: Not only are youth-led groups the most popular individually, but the most central nodes are Sunrise and US Youth Climate Strike, which are youth-led groups based in the US, which are connected through various activists to the internationally focused youth-led group Fridays for Future. It is also worth noting that Sunrise, which gained notoriety when its members occupied Nancy Pelosi's office in December 2018 calling for a Green New Deal (Sonmez, 2018), is connected to every other group in the network through at least one member. In this network, adult-led groups play a relatively peripheral role; only Extinction Rebellion connects to the most central youth-led organizations.

\subsubsection{September 2019 Climate Strike Affiliation} Network

When we look at the affiliation network of hosts from the September 2019 climate strikes presented in Figure 2, we see clear evidence of changes in the organizational coalition. Although Sunrise continues to be the central node in the network with connections to numerous other youth-led groups, adult-led groups have started to play a larger role in the coalition. It is worth noting that in September 2019, Fridays for Future is no longer playing a prominent role in the network. Moreover, this group that was formed in response to the organizing efforts of Greta Thunberg is the only youth-led group that is not directly connected to the most prominent group: Sunrise. Instead, the adult-led 350 plays a much bigger role during this wave, even though it is only directly connected to two groups: Sunrise and the adult-led Sierra Club.

\subsubsection{Earth Day Live Affiliation Network}

Sunrise continues to play a central role in the affiliation network of organizers during the Earth Day Live event, which is presented in Figure 3. In fact, during this wave,

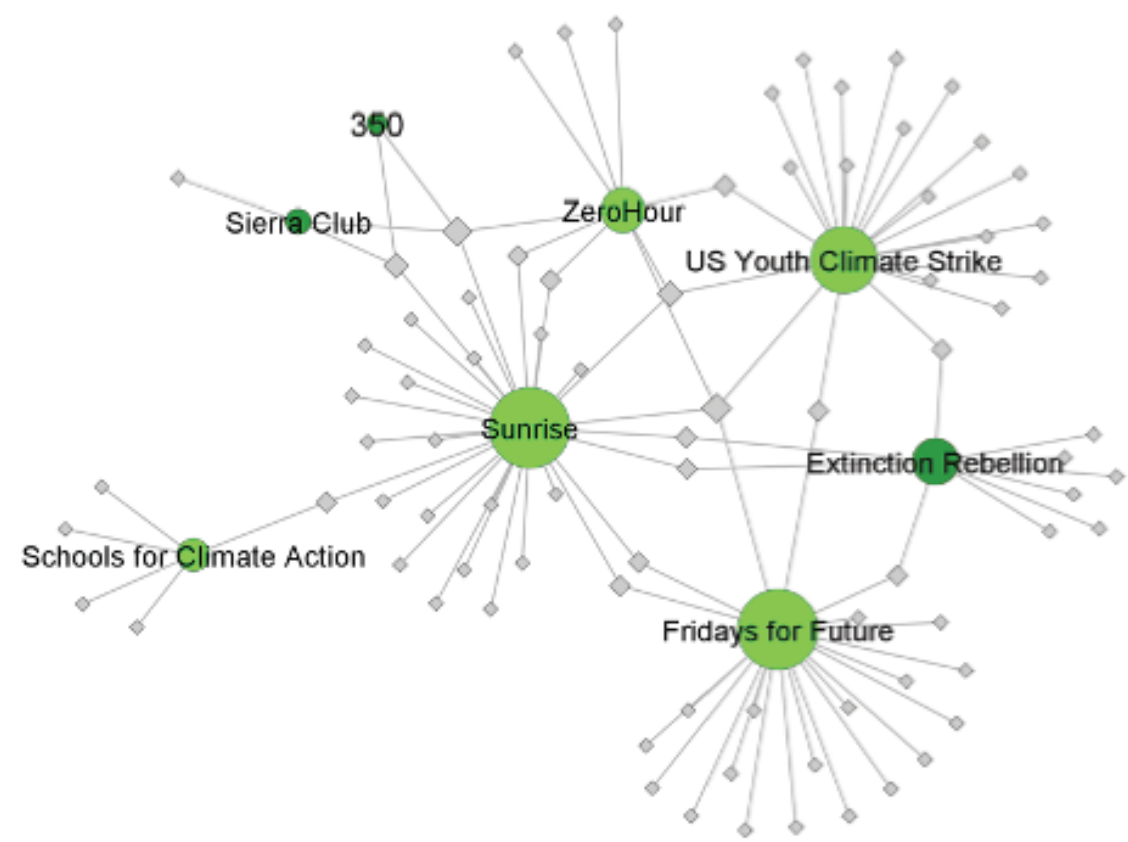

Figure 1. Affiliation network for Spring 2019 strikes. 


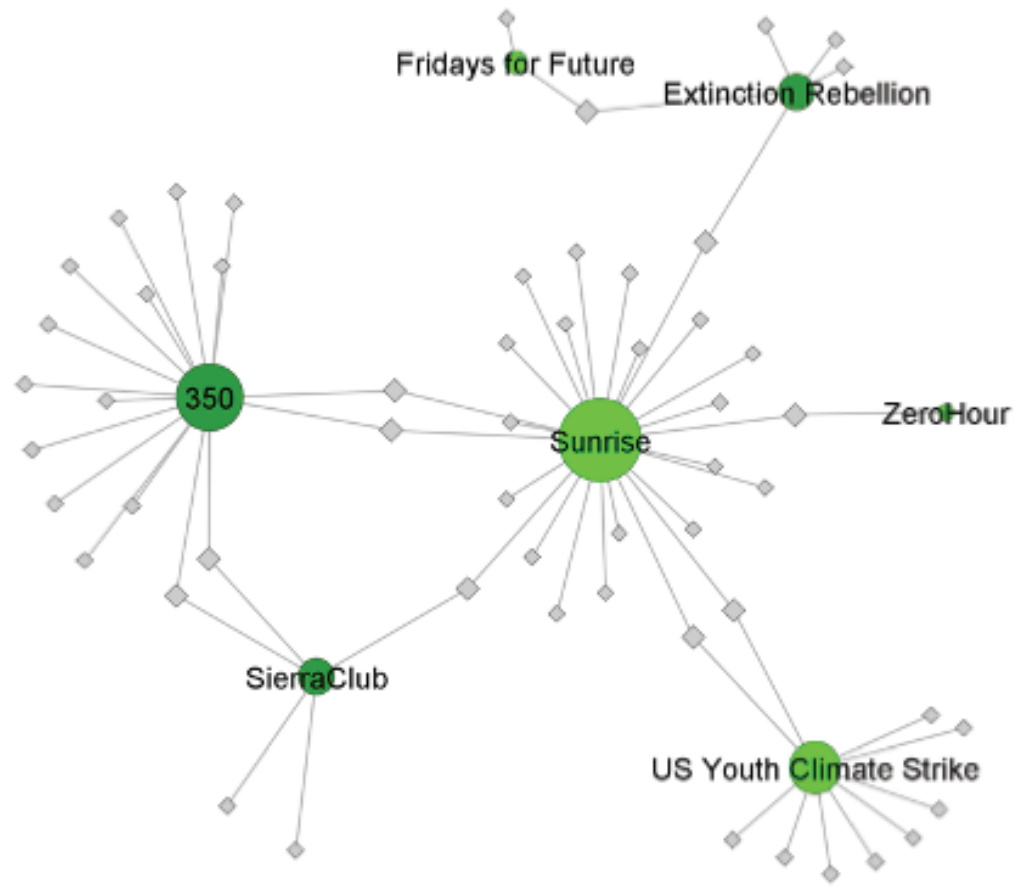

Figure 2. Affiliation network of organizers for September 2019 strikes.

Sunrise members report being affiliated with every other top organization in the network except for Schools for Climate Action, which is not a central group in this network. In contrast to the previous waves of the study, the other two top groups in this network are adult-led 350 and Sierra Club. The April 2020 network is denser, with the adult-led groups all being connected to one another as well as to the numerous other youth-led groups.

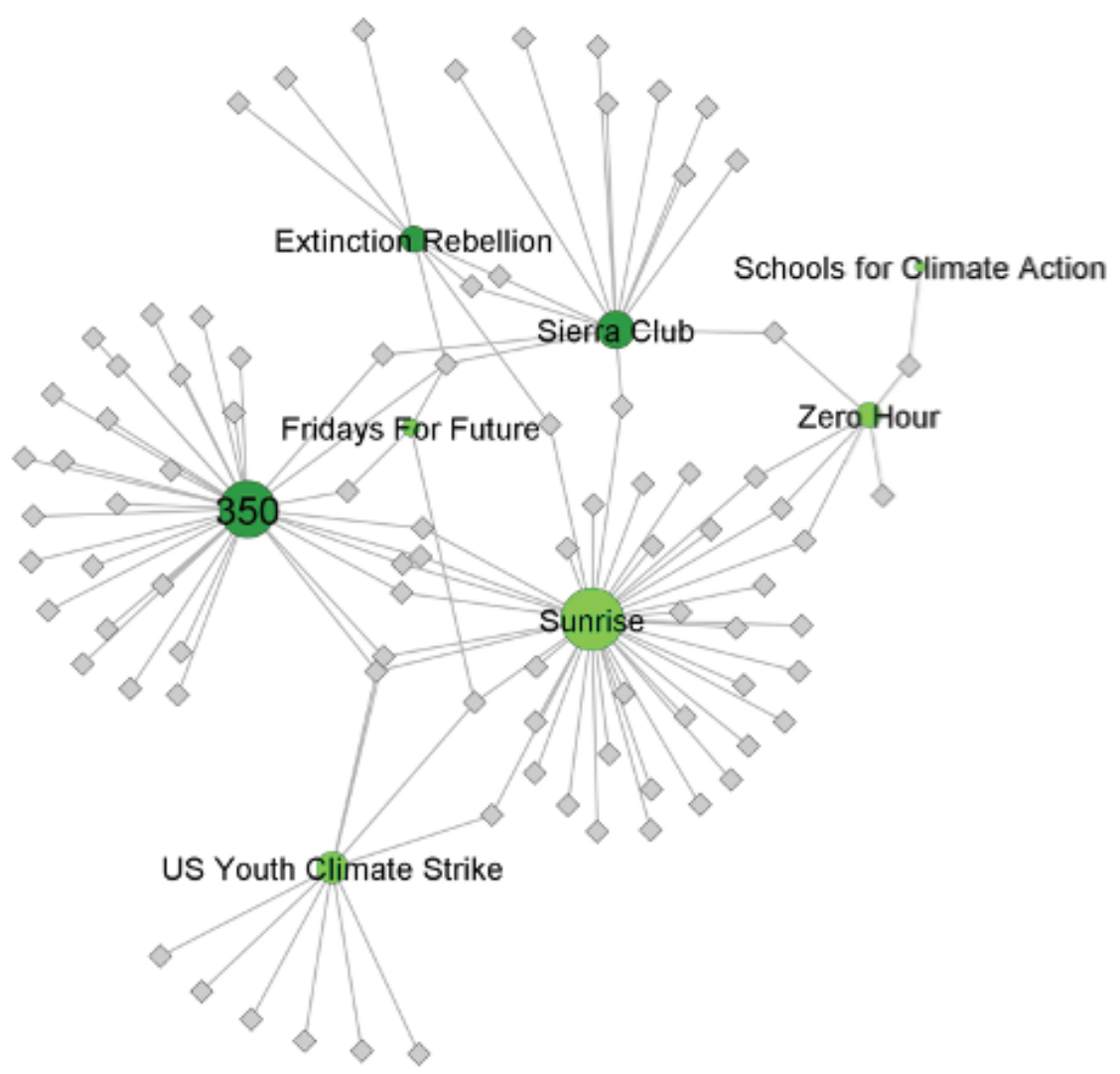

Figure 3. Affiliation network for organizers of Earth Day Live, April 2020. 


\section{Conclusions}

By analyzing the affiliation networks of the local hosts from three waves of climate activism in the US, we see clear evidence about how the coalition of this movement has changed. Across all waves of activism, we do not see evidence of groups that span movement boundaries playing a large role in the coalition (Beamish \& Luebbers, 2009; Wang et al., 2018; see also Goss \& Heaney, 2010). Rather, the coalition continues to be led by groups with a mission to address the climate crisis. We also do not see clear evidence of intersectionality in terms of the identities of the members of the groups in these coalitions (Carastathis, 2013). To the degree that age can be an identity, we do see evidence that the youth-led groups, which tend to have less professionalized leadership and structure, were supplanted over time by adult-led organizations. In other words, although it began as a clear case of youth-led activism, by spring 2020, the coalition was being led by a combination of youth and adult-led groups. Not only did the median age of the organizers go up substantially during the period of study, but the organizational coalition shifted to include a number of adult-led groups that were playing a more central role.

This change is due, in part, to the duration of the climate struggle. As research has documented, more professionalized organizations-like 350 or Sierra Clubplay important roles in sustaining activism (Staggenborg, 1991). Well-established organizations that have consistent funding streams and long-term members sustain participation and activism during the slower and more difficult periods. It is worth repeating that 350 was started in 2008 by a group of young people working with activist Bill McKibben to stop the climate crisis, but these young people have grown up and the organization has professionalized over the past 12 years.

At the same time, our findings also provide evidence of the ways that external factors and political opportunities affect coalitions (Meyer \& Corrigall-Brown, 2005). In this case, the Covid-19 pandemic and all the subsequent Covid-19-related changes to opportunities for activism during stay-at-home orders are likely to have played a substantial role in the changes in the coalition and the movement. In their recent assessment of this cycle of climate activism internationally, de Moor et al. (2020, p. 1) note that the pandemic "arguably marks the end of the first chapter of the recent climate protest cycle." Although we believe that it is premature to determine if the cycle is completed, there is no question that the pandemic and the changes in protesting behavior due to it, had a direct effect on the trajectory of the movement in terms of who was involved and what tactics they employed.

As the pandemic wears on, school strikes continue to be held mostly indoors and on social media, which has reduced participation considerably. With professional adult-led groups playing a more central role in the coalition, one might expect the movement to focus on more mainstream tactics (like demonstrating on a weekend rather than during the school day when participants must skip school) and to redirect its efforts beyond young people. Instead of following this trajectory, much of the work of the youth climate movement in the US since the Earth Day Live event in April 2020 involved a redirection of efforts away from the tactic of the climate strike.

In summer 2020, huge demonstrations took place across the US in response to the police killing of unarmed Black citizens including George Floyd and Breonna Taylor. In response, a number of youth-led climate groupsincluding the Strike With Us coalition of youth climate groups, which includes Sunrise-called for their members to mobilize in solidarity with the Black Lives Matter movement (Strike With Us, 2020; Sunrise Team, 2020a). In addition, these groups focused much of their efforts during the second half of 2020 on mobilizing young people to participate in the election. Sunrise, in particular, received a lot of media attention for its work around the election and in swing states (see e.g., Arrieta-Kenna, 2019) and the group announced a new program to support young people to run for political office in Fall 2020 (Sunrise Team, 2020b). Such efforts provide clear evidence that, even though the tactic of the school strike has become less common, the youth climate movement in the US continues.

It is important to highlight here that comparisons between the movement in the US and in other parts of the world should be interpreted with caution. Not only is the trajectory of the movement broader than the time period of our study, but the US case is very much a product of the political and organizational landscape of America. As has been noted elsewhere (Fisher, 2019c), climate strikes began during a time of heightened contention in the US, and many participants in these strikes reported very high levels of engagement in other protests as part of the anti-Trump Resistance prior to participating in climate activism through school strikes. Moreover, there were already a number of organizations, including Sunrise, working within the youth climate space in the US before the first climate strikes began in this country (Sonmez, 2018; see also Arrieta-Kenna, 2019). When the tactic of the school strike became popular, these more established organizations played an important role in supporting the network of activists participating in the movement. As has been previously noted, such groups are always more capable of sustaining and supporting activism over time and they are now leading the movement to engage in other tactics.

The findings from this study of the youth climate movement in the US point to some clear opportunities for future research. First and foremost, this study provides a snapshot of a limited period of time in the youth climate movement in the US. Future research must continue to study this movement, focusing on the individuals participating and the organizations involved to understand the broader trajectory of the long-term climate struggle. It is unclear the degree to which our 
findings in the US would be different if data collection had begun earlier as groups were just beginning to organize climate strikes or if a global pandemic had not occurred.

Moreover, as the tactics of the movement have shifted, it is important to look at the ways the coalition of organizations involved in the movement has also changed. In particular, future research should explore what role resources, organizational structures, political opportunities, and tactics play in the trajectory of the youth climate movement. Although such research should continue to collect extensive data through surveys, it would benefit from integrating intensive open-ended semi-structured interviews with individual activists and organizational representatives. Future research is also needed to explore in more detail the role that local hosts are playing within the movement. Although there is scant evidence that these individuals were central to decisionmaking around the national climate strikes, future investigation can help us understand what roles they may be playing in coordinating climate activism in their communities and sustaining activism at the local level. Finally, following the recommendations from Fisher and Nasrin (2020), research should aim to connect this climate activism to its broader effects on the individuals and organizations involved, the policies they are aiming to influence, and the material outcomes of these efforts in terms of actual environmental changes.

\section{Acknowledgments}

Research for this project was funded, in part, through a grant from the William and Flora Hewlett Foundation. The authors would like to thank the Academic Editors and two anonymous reviewers for their comments on an earlier draft of this article.

\section{Conflict of Interests}

The authors declare no conflict of interests.

\section{References}

350.org Team. (2019, September 28). 7.6 million people demand action after week of climate strikes. 350.org Team. Retrieved from https://350.org/7-millionpeople-demand-action-after-week-of-climatestrikes

350.org Team. (2021, March 24). About 350. 350.org Team. Retrieved from https://350.org/about

Adam, E. M. (2017). Intersectional coalitions: The paradoxes of rights-based movement building in LGBTQ and immigrant communities. Law \& Society Review, 51(1), 132-167.

Arrieta-Kenna, R. (2019, June 16). The Sunrise movement actually changed the democratic conversation: So what do you do for a sequel? Politico. Retrieved from https://politi.co/2WJnla2

Barkan, S. E. (1979). Strategic, tactical and organizational dilemmas of the protest movement against nuclear power. Social Problems, 27(1), 19-37.

Beamish, T. D., \& Luebbers, A. J. (2009). Alliance building across social movements: Bridging difference in a peace and justice coalition. Social Problems, 56(4), 647-676.

Bliuc, A.-M., Betts, J., Vergani, M., Iqbal, M., \& Dunn, K. (2019). Collective identity changes in far-right online communities: The role of offline intergroup conflict. New Media \& Society, 21(8), 1770-1786.

Borland, E. (2008). Social movement organizations and coalitions: Comparisons from the women's movement in Buenos Aires, Argentina. In P. G. Coy (Ed.), Research in social movements, conflicts and change (pp. 83-112). Bingley: Emerald Group Publishing Limited.

Carastathis, A. (2013). Identity categories as potential coalitions. Signs, 38(4), 941-965.

Carbado, D. W. (2013). Colorblind Intersectionality. Signs: Journal of Women in Culture and Society, 38(4), 811-845.

Cárdenas, D., \& de la Sablonnière, R. (2020). Intergroup conflict and the process of social change: Similar conflicts, different intragroup processes. Peace and Conflict: Journal of Peace Psychology, 26(3), 303-313.

Carrington, D. (2019, March 19). School climate strikes: 1.4 million people took part, say campaigners. The Guardian. Retrieved from https://www. theguardian.com/environment/2019/mar/19/ school-climate-strikes-more-than-1-million-tookpart-say-campaigners-greta-thunberg

Cho, S., Crenshaw, K. W., \& McCall, L. (2013). Toward a field of intersectionality studies: Theory, applications, and praxis. Signs: Journal of Women in Culture and Society, 38(4), 785-810.

Choo, H. Y., \& Ferree, M. M. (2010). Practicing intersectionality in sociological research: A critical analysis of inclusions, interactions, and institutions in the study of inequalities. Sociological Theory, 28(2), 129-149.

Collins, P. H. (2002). Black feminist thought: Knowledge, consciousness, and the politics of empowerment. London: Routledge.

Crenshaw, K. W. (1991). Mapping the margins: Intersectionality, identity politics, and violence against women of color. Stanford Law Review, 43(6), 1241-1299.

de Moor, J., De Vydt, M., Uba, K., \& Wahlström, M. (2020). New kids on the block: Taking stock of the recent cycle of climate activism. Social Movement Studies. https://doi.org/10.1080/14742837.2020. 1836617

Diani, M. (1995). Green networks: A structural analysis of the Italian environmental movement. Edinburgh: Edinburgh University Press.

Diani, M. (2007). Networks and participation. In D. A. Snow, S. A. Soule, \& H. Kriesi (Eds.), The Blackwell companion to social movements (pp. 339-359). New York, NY: John Wiley \& Sons. 
Diani, M. (2010). Promoting the protest: The organizational embeddedness of the demonstrators. In S. Walgrave \& D. Rucht (Eds.), The world says no to war: Demonstrations against the war on Iraq (pp. 194-214). Minneapolis, MN: University of Minnesota Press.

Diani, M., Lindsay, I., \& Purdue, D. (2010). Sustained interactions? Social movements and coalitions in local settings. In N. Van Dyke \& H. J. McCammon (Eds.), Strategic alliances: Coalition building and social movements (pp. 219-238). Minneapolis, MN: University of Minnesota Press.

Diani, M., \& McAdam, D. (Eds.). (2003). Social movements and networks: Relational approaches to collective action. Oxford and New York, NY: Oxford University Press.

Ehrenreich, N. (2002). Subordination and symbiosis: Mechanisms of mutual support between subordinating systems. UMKC Law Review, 71(2), 251-324.

Evensen, D. (2019). The rhetorical limitations of the \#FridaysForFuture movement. Nature Climate Change, 9(6), 428-430.

Fantasia, R., \& Stepan-Norris, J. (2007). The labor movement in motion. In D. A. Snow, S. A. Soule, \& H. Kriesi (Eds.), The Blackwell companion to social movements (pp. 555-575). Oxford: Blackwell Publishing Ltd.

Fantasia, R., \& Voss, K. (2004). Hard work: Remaking the American labor movement. Berkeley, CA: University of California Press.

Ferree, M. M., \& Hess, B. (2016). Controversy and coalition: The new feminist movement across four decades of change. London: Routledge.

Fisher, D. R. (2019a). American resistance: From the women's march to the blue wave. New York, NY: Columbia University Press.

Fisher, D. R. (2019b). The broader importance of \#FridaysForFuture. Nature Climate Change, 9(6), 430-431.

Fisher, D. R. (2019c, July 12). The Youth Climate Summit starts July 12. It's full of young activists trained in the anti-Trump movement. The Washington Post. Retrieved from https://www.washingtonpost. com/politics/2019/07/12/youth-climate-summitstarts-today-its-full-young-activists-trained-antitrump-movement

Fisher, D. R., Andrews, K. T., Caren, N., Chenoweth, E., Heaney, M. T., Leung, T., . . . Pressman, J. (2019). The science of contemporary street protest: New efforts in the United States. Science Advances, 5(10). https:// doi.org/10.1126/sciadv.aaw5461

Fisher, D. R., Dow, D. M., \& Ray, R. (2017). Intersectionality takes it to the streets: Mobilizing across diverse interests for the Women's March. Science Advances, 3(9). https://doi.org/10.1126/sciadv.aao1390

Fisher, D. R., Jasny, L., \& Dow, D. M. (2018). Why are we here? Patterns of intersectional motivations across the resistance. Mobilization: An International Quarterly, 23(4), 451-468.
Fisher, D. R., \& Nasrin, S. (2020). Climate activism and its effects. WIREs Climate Change. https://doi.org/ $10.1002 /$ wcc.683

Freeman, J. (1972). The tyranny of structurelessness. Berkeley Journal of Sociology, 17, 151-164.

Gamson, W. A. (1990). The strategy of social protest (2nd ed.). Belmont, CA: Wadsworth Pub.

Giugni, M., \& Grasso, M. T. (2015). Environmental movements in advanced industrial democracies: Heterogeneity, transformation, and institutionalization. Annual Review of Environment and Resources, 40(1), 337-361.

Goss, K. A., \& Heaney, M. T. (2010). Organizing women as women: Hybridity and grassroots collective action in the 21st century. Perspectives on Politics, 8(1), 27-52.

Gould, R. V. (1991). Multiple networks and mobilization in the Paris Commune, 1871. American Sociological Review, 56(6), 716-729.

Grimm, J. J. (2019). Egypt is not for sale! Harnessing nationalism for alliance building in Egypt's Tiran and Sanafir island protests. Mediterranean Politics, 24(4), 443-466.

Hancock, A.-M. (2007). When multiplication doesn't equal quick addition: Examining intersectionality as a research paradigm. Perspectives on Politics, 5(1), 63-79.

Heaney, M. T., \& Rojas, F. (2008). Coalition dissolution, mobilization, and network dynamics in the US antiwar movement. In P.G. Coy (Ed.), Research in social movements, conflicts and change (pp. 39-82). Bingley: Emerald Group Publishing Limited.

Heaney, M. T., \& Rojas, F. (2015). Party in the street: The antiwar movement and the Democratic Party after 9/11. Cambridge: Cambridge University Press.

Kim, H., \& Bearman, P. S. (1997). The structure and dynamics of movement participation. American Sociological Review, 62(1), 70-93.

Klandermans, B., \& Oegema, D. (1987). Potentials, networks, motivations, and barriers: Steps towards participation in social movements. American Sociological Review, 52(4), 519-531.

Levi, M., \& Murphy, G. H. (2006). Coalitions of contention: The case of the WTO protests in Seattle. Political Studies, 54(4), 651-670.

Lichterman, P. (1996). The search for political community: American activists reinventing commitment. Cambridge: Cambridge University Press.

Martiskainen, M., Axon, S., Sovacool, B. K., Sareen, S., Furszyfer Del Rio, D., \& Axon, K. (2020). Contextualizing climate justice activism: Knowledge, emotions, motivations, and actions among climate strikers in six cities. Global Environmental Change, 65. https:// doi.org/10.1016/j.gloenvcha.2020.102180

Marwell, G., Oliver, P. E., \& Prahl, R. (1988). Social networks and collective action: A theory of the critical mass, III. American Journal of Sociology, 94(3), 502-534. 
McAdam, D. (1982). Political process and the development of Black insurgency, 1930-1970, (2nd ed.). Chicago, IL: The University of Chicago Press.

McAdam, D. (1983). Tactical innovation and the pace of insurgency. American Sociological Review, 48(6), 735-754.

Meyer, D., \& Corrigall-Brown, C. (2005). Coalitions and political context: U.S. movements against wars in Iraq. Mobilization: An International Quarterly, 10(3), 327-344.

Meyer, D. S., \& Whittier, N. (1994). Social movement spillover. Social Problems, 41(2), 277-298.

Milkman, R. (2017). A new political generation: Millennials and the post-2008 wave of protest. American Sociological Review, 82(1), 1-31.

Mische, A., \& Pattison, P. (2000). Composing a civic arena: Publics, projects, and social settings. Poetics, 27(2), 163-194.

Morris, A. D. (1993). Birmingham confrontation reconsidered: An analysis of the dynamics and tactics of mobilization. American Sociological Review, 58(5), 621-636.

Park, H. (2008). Forming coalitions: A network-theoretic approach to the contemporary South Korean environmental movement. Mobilization: An International Quarterly, 13(1), 99-114.

Passy, F. (2003). Social networks matter: But how? In M. Diani \& D. McAdams (Eds.), Social movements and networks: Relational approaches to collective action (pp. 21-47). Oxford: Oxford University Press.

Polletta, F. (2002). Plotting protest. In J. E. Davis (Ed.), Stories of change: Narrative and social movements (pp. 31-51). Albany, NY: SUNY Press.

Reagon, B. J. (1983). Coalition politics: Turning the century. In B. Smith (Ed.), Home girls: A Black feminist anthology (1st ed., pp. 356-368). New Burnswick, NJ: Kitchen Table: Women of Color Press.

Roberts, D., \& Jesudason, S. (2013). Moverment intersectionality: The case of race, gender, disability, and genetic technologies. Du Bois Review: Social Science Research on Race, 10(2), 313-328.

Rosenthal, N., Fingrutd, M., Ethier, M., Karant, R., \& McDonald, D. (1985). Social movements and network analysis: A case study of nineteenth-century women's reform in New York State. American Journal of Sociology, 90(5), 1022-1054.

Saunders, C., Grasso, M., Olcese, C., Rainsford, E., \& Rootes, C. (2012). Explaining differential protest participation: Novices, returners, repeaters, and stalwarts. Mobilization: An International Quarterly, 17(3), 263-280.

Shaffer, M. B. (2000). Coalition work among environmental groups. In P. G. Coy (Ed.), Research in social movements, conflicts and change (Vol. 22, pp. 111-126). Bingley: Emerald.

Shows, C., \& Gerstel, N. (2009). Fathering, class, and gender: A comparison of physicians and emergency medical technicians. Gender and Society, 23(2), 161-187.
Sonmez, F. (2018, November 13). Ocasio-Cortez rallies protesters at Pelosi's office, expresses admiration for leader. The Washington Post. Retrieved from https:// www.washingtonpost.com/politics/ocasio-cortezaddresses-environmental-protesters-waging-sit-inin-pelosis-office/2018/11/13/abd39c38-e766-11e8bbdb-72fdbf9d4fed_story.html

Staggenborg, S. (1991). The pro-choice movement: Organization and activism in the abortion conflict. Oxford: Oxford University Press.

Steedly, H. R., \& Foley, J. W. (1979). The success of protest groups: Multivariate analyses. Social Science Research, 8(1), 1-15.

Strike With Us. (2020, October 21). You striked with us and voted with us. Strikewithus.org. Retrieved from https://strikewithus.org

Sunrise Team. (2020a). Sunrise taking actions for black lives. Sunrise. Retrieved from https://docs. google.com/document/d/1rwcHn_2KNbeom_ 6lk2ENgGDAQW21cxaVFSZZamOrNYM/edit\#

Sunrise Team. (2020b). Sunrise candidate program. Sunrise. Retrieved from https://www.sunrisemovement. org/sunrise-candidate-program

Swank, E., \& Fahs, B. (2013). An intersectional analysis of gender and race for sexual minorities who engage in gay and lesbian rights activism. Sex Roles, 68(11/12), 660-674.

Terriquez, V. (2015). Intersectional mobilization, social movement spillover, and queer youth leadership in the immigrant rights movement. Social Problems, 62(3), 343-362.

Thomas, J. B., \& Trevino, L. K. (1993). Information processing in strategic alliance building: A multiple-case approach. Journal of Management Studies, 30(5), 779-814.

Thunberg, G. (2019, May 23). Young people have led the climate strikes. Now we need adults to join us too. The Guardian. Retrieved from https://www. theguardian.com/commentisfree/2019/may/23/ greta-thunberg-young-people-climate-strikes-20september

Thunberg, G. (2020, August 19). After two years of school strikes, the world is still in a state of climate crisis denial. The Guardian. Retrieved from http:// www.theguardian.com/commentisfree/2020/aug/ 19/climate-crisis-leaders-greta-thunberg

Valentine, G. (2007). Theorizing and researching intersectionality: A challenge for feminist geography. The Professional Geographer, 59(1), 10-21.

Van Dyke, N. (2003). Crossing movement boundaries: Factors that facilitate coalition protest by American college students, 1930-1990. Social Problems, 50(2), 226-250.

Van Dyke, N., \& McCammon, H. J. (2010). Strategic alliances: Coalition building and social movements. Minneapolis, MN: University of Minnesota Press.

Wadsworth, N. D. (2011). Intersectionality in California's same-sex marriage battles: A complex proposition. 
Political Research Quarterly, 64(1), 200-216.

Wang, D., Piazza, A., \& Soule, S. A. (2018). Boundaryspanning in social movements: Antecedents and outcomes. Annual Review of Sociology, 44, 167-187.
Wingfield, A. H. (2009). Racializing the glass escalator: Reconsidering men's experiences with women's work. Gender and Society, 23(1), 5-26.

\section{About the Authors}

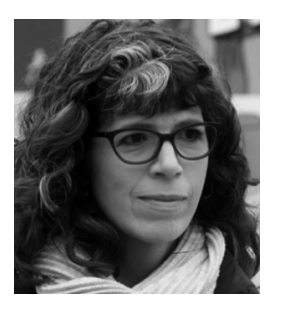

Dana R. Fisher is a Professor in the Department of Sociology at the University of Maryland. Her research focuses on studying democracy, civic participation, activism and environmental policymaking. She has authored over 65 peer-reviewed research papers and book chapters, and has written six books, including American Resistance (Columbia University Press, 2019). She is currently serving as a Contributing Author for Working Group 3 of the IPCC's Sixth Assessment writing about civic engagement and activism.

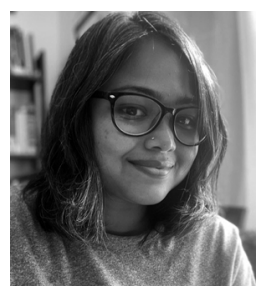

Sohana Nasrin is a PhD Candidate at the Philip Merrill College of Journalism at the University of Maryland, College Park. Sohana studies the often-complicated relationship between journalism and activism, oppositional media practices, visuals, and climate change communication. Her current research focuses on the activism and journalism of the youth climate movement. 